\title{
Influence of Liquidity on Idiosyncratic Volatility of Stock Returns among Listed Firms in Kenya
}

\author{
Job Cheruiyot Aiyabei* Dr. Olweny Tobias Dr. Irungu Macharia \\ School of Human Resource Development, Jomo Kenyatta University of Agriculture and Technology, \\ P.O BOX 00200-62000, Nairobi, Kenya
}

\begin{abstract}
Idiosyncratic volatility has not always been taken into consideration in asset pricing; this is as a result of capital asset pricing model's proposition that idiosyncratic volatility is diversified away and market investors always hold a well-diversified portfolio. However, in reality, this does not always hold true. Studies have shown that investors do not always hold diversified portfolios and idiosyncratic risk is priced to indemnify investors for their inability to hold market portfolios, the main objective of this study was therefore to establish the effect of financial statement information on idiosyncratic volatility of stocks return among listed firms in Kenya. Idiosyncratic volatility was the dependent variable while independent variable was listed firm's liquidity (Current ratio). The study used correlational and descriptive research design, it also used census technique which targeted all 39 listed companies that existed and their shares were actively traded at the Nairobi Securities Exchange (NSE) from the year 1998 to 2017. STATA was used to generate Descriptive and inferential statistics. The study employed a dynamic panel data regression model, the analysis of variance (ANOVA) was employed to reveal the overall model significance, the calculated F-statistic was compared with the tabulated F-statistic and a critical p-value of 0.05 was used to determine whether the overall model is significant. The study results found that there was a negative and significant relationship between liquidity and Idiosyncratic Volatility of stock returns among listed firms in Kenya $(\mathrm{r}=-0.020, \mathrm{p}=0.000)$, and therefore the null hypotheses were rejected. Based on the findings, the study concluded that, liquidity has a significant relationship with Idiosyncratic Volatility of stock returns among listed firms in Kenya. The study recommends management to focus on developing financial accounting systems and processes that will result in realization of financial statements that reflect true and fair representation of the listed companies' financial position, they should also disclose all material information that is relevant for stakeholder's decision making. The study also recommends that the management should regularly monitor the company's liquidity ratio as this ensures sound and informed decisions that will increase the company's profits, drive growth and reduce Idiosyncratic risk.
\end{abstract}

Keywords: Liquidity per Share, Idiosyncratic Volatility, Stock Returns, NSE \& Kenya.

DOI: $10.7176 /$ RJFA/10-22-02

Publication date: November $30^{\text {th }} 2019$

\subsection{Introduction}

The value relevance of published financial statement has increased significantly over the last fifteen years; this can be accredited to harmonization of accounting standards from the year 2001 as well as adoption of international financial reporting standard (IFRS) and international accounting standards (IAS) by a significant number of jurisdictions around the word. all countries with well-functioning financial market have adopted IFRS or some form of structured financial reporting that is similar to international accounting standard (Riscura, 2013). Studies have also shown that there is correlation between accounting information and equity price volatility in the securities market Zhou (2004), Sharma (2011), Halonen, Pavlovic and Persson (2013)

Volatility is a measure of dispersion around the mean or average return of an asset. It also measures the range of an asset price about its mean level over a fixed time period (Abken and Nandi, 1996). Volatility is associated with variance of a share price. If a stock is regarded as volatile, then it is likely that it will experience a systematic variance of its mean over a given time period. On the other hand, a less volatile stock will have a market price that will slightly deviate over time. Idiosyncratic volatility is a risk that has little or absolutely no correlation with market risk but is specific to an asset or small group of related assets (Boloorforoosh, 2014).

The use of published financial statements and its relevant financial information disclosures in investment decision at the securities exchange and its subsequent impact on the company's market price volatility has not been studied widely in Sub-Saharan Africa, studies that has been undertaken elsewhere have shown mixed results. After analyzing the effect of cash EPS, EPS and BVPS on the equity prices of companies listed in the Swedish securities exchange market, Halonen and Pavlovic (2013) found that share price volatility is significantly affected by accounting information. According to Spiegel and Wang (2005) idiosyncratic volatility and liquidity have an inversely relationship and conclude that the correlation between idiosyncratic volatility and market returns could also indicate both the relationship between liquidity and returns and the correlation between firm size and returns.

According to Wang and Chang (2008), there exist a significant and positive association linking stock price 
and book value and also between equity price and EPS at the Taiwanese stock exchange. De, Medeiros \& Lago (2014) investigated the relationship between financial accounting information and volatility of share returns in listed Brazilian firms, the empirical findings showed that the level of financial accounting information disclosure has a significant and negative effect on securities market risk measured by stock return volatility. Almeri, AlFarah, and Shanikat (2014) study did not find significant correlation between accounting information variables and stock volatility with the financial accounting information only explaining $2.6 \%$ of the volatility experienced in the stock prices.

Studies has also found that, for some reasons, investors always do not hold diversified portfolio which usually eliminate significantly idiosyncratic volatility as supported by CAPM (Fazil, 2013). Other studies document that investors do not react to published accounting information even when it leads sharp movement in stock prices (Bushee \& Noe (2000); Gleason \& Lee (2003). Therefore, investors who are not able to diversify their portfolios should consider idiosyncratic risk beside systematic risk in projecting expected market return. This paper therefore seeks to establish the effects of liquidity on idiosyncratic volatility of stock returns among listed firms in Kenya.

\subsection{Problem Statement}

Idiosyncratic volatility has not always been taken into consideration in asset pricing; this is as a result of CAPM's proposition that idiosyncratic volatility is diversified away and market investors always hold a welldiversified market portfolio (Sandberg,2005). However, in reality, this does not always hold true. According to (Fu, 2009; Eiling, 2008; Malkiel and Xu, 2006; Fazil, 2013; Boloorforoosh, 2014) investors do not always hold diversified portfolios and idiosyncratic risk is priced to indemnify investors for their inability to hold the market portfolio. With the increase in studies stipulating that published financial information affects market price volatility (Yu and Huang, 2005; Sharma, 2011; Glezakos, 2012; Sibel, 2013), and with the significant growth of the Nairobi Securities exchange over the last decade, (Kihara, 2011), there is need to find out the effect of financial statement information on equities price volatility. Halonen, Pavlovic and Persson (2013) examined the effect of BVPS, EPS and DPS on price movement on firms listed in the Swedish securities exchange, they found that published financial data explains equity price movement and volatility at the exchange. Wang and Chang (2008) found that there was a positive and significant correlation between firm's book value and equity price and also between EPS and share price listed at Taiwan SEC. Wang and Luo (2013) studied the relationship between accounting information and stock price reactions in Shanghai securities market, they found that equity price and accounting information were positively correlated, but the degree of significant varies; return on equity and EPS were the most significantly correlated.

After examining the impact of BVPS, EPS and DPS on the share price movement of listed firms, Halonen, Pavlovic and Persson (2013) found that accounting information explains a significant portion of share price movement at the Swedish securities exchange. Abo-Osba (2007) found a positive, strong and statistically significant relationship between stock prices volatility and accounting variables. Wang and Chang (2008) studies found that there was a positive and significant relationship between listed firms book value and share price and also between EPS and listed stock price at the Taiwan SEC. Wang and Luo (2013) analyzed the relationship between financial accounting data and stock price reactions in Shanghai securities market, they found that equity price and accounting information were positively correlated, but the degree of significant varies; return on equity and EPS were the most significantly correlated. In his study, Gachucha (2014) found strong and positive relationship between return on investment, DPS, current ratio, and positive \& weak correlation between debt to equity ratio and volatility in equities returns.

Other research studies have resulted in conflicting and mixed findings. AL-Farah, Almeri \& Shanikat (2014) found that financial information explained only $3.8 \%$ of market volatility while $96 \%$ of equity price movement is attributed to other factors. After studying the relationship between dividend yield, payout ratio and listed firms' volatility of equity price at the London securities exchange, Hussainey and Mgbame (2011) found a significant and negative correlation between the financial data and firms' volatility. On the other hand, Xing and Zhang (2008) study targeting G7 counties, found a negative relationship between EPS and idiosyncratic volatility. Almeri, Al-Farah, and Shanikat (2014) did not find a significant relationship between financial accounting variables and stock volatility.

These mixed and contradictory findings form the basis of undertaking this study. This study therefore sought to establish the effect of liquidity on idiosyncratic volatility of stocks return listed at the Nairobi securities exchange.

\subsection{Objective of the Study}

To establish the effect of firm liquidity on idiosyncratic volatility of stock returns among listed firms in Kenya. 


\subsection{Research Hypothesis}

$\mathbf{H}_{\mathbf{0}}$ : Firms liquidity has no significant effect on idiosyncratic volatility of stock returns among listed firms in Kenya.

\subsection{Scope of the Study}

The study considered liquidity data from listed firms published financial statement information. This study took into consideration only the companies that existed and their shares were actively traded at the NSE from the year 1998 to the year 2017. Following the criterion employed by Fu (2009), the researcher zeroed in on the stocks that were traded for a minimum of 15 days during each month of the sample period

\subsection{Literature Review}

\subsubsection{Theoretical Literature: Liquidity preference theory}

Liquidity preference theory was first developed by John M. Keynes explained in his book; The General Theory of Employment, Interest and Money (1936) he sought to explain of interest rate by supply and demand of money. Keynes (1936) further identified three motives that determines the demand for liquidity; transactions motive for basic day to day expenditure needs, precautionary motive to provide a reservoir for unanticipated expenditures and the speculative motive as a desire or expectation of interest rates on alternative assets to rise. The transactional demand for money is associated with the desire for cash balance the is required to meet current assets and general business transactional requirements (Okpara 2010).

Jhingan, (2004) indicated that, people who hold money or how have an expectation that cash balance is going to exceed the yield on a substitute asset are said to display liquidity preferences. Andabai (2010) is of the point of view that speculative demand for money and liquidity preference are suggested to have an relationship to the level of interest rates. According to Uchendu (2010), interest rate have the following functions; it retains the available supply of credit, it brings assurance that the current savings will be utilized in investment so as to promote economy growth, it provides funds to investment projects with the highest expected return, and provide sufficient supply of money balancing the policies of money demand. It is also an important instrument for government policy that affects the general public savings and investment (Akpan, 2004).

\subsection{Conceptual Framework}

The independent variable in this study effect of financial statement information on idiosyncratic volatility of stocks listed at the NSE is Liquidity, which affect the dependent, Idiosyncratic volatility of listed stocks as shown in Figure 1.

\begin{tabular}{|l|l|}
\hline $\begin{array}{l}\text { Liquidity } \\
\text {-Current ratio }\end{array}$ & $\begin{array}{l}\text { Idiosyncratic Volatility } \\
\text { Standard deviation of the residual } \\
\left(\varepsilon_{\text {it }}\right) \text { from single index model }\end{array}$ \\
\cline { 2 - 3 } & \\
\hline Independent Variable & Dependent Variable \\
\hline
\end{tabular}

\subsection{Empirical Review}

\subsubsection{Firm Liquidity and Idiosyncratic Volatility}

Liquidity reflects the capability of a company to pay its current liability when they fall due by using the assets that are easily convertible into liquid cash. According to Gachucha (2014), who investigated the relationship between stock returns at the NSE and financial management practices; He evaluated five year published financial statements of 29 firms listed at the Nairobi Securities Exchange for the periods 2008 to 2012. The study concluded that dividend policies, liquidity management, financing activities and investing decisions explained $65 \%$ of stock return volatility whereas $35 \%$ of the movement in stock returns is attributed to other reasons. Hodrick and Zhang (2009) concluded that reduced future returns is primarily as a results of high idiosyncratic volatility stocks. However, their previous study found that there exists a negative correlation between one month lagged idiosyncratic volatility and stocks monthly return

Nyamai (2012) study on the impact of liquidity, and cash management on share prices of listed companies at the NSE, he concluded that liquidity has a positive impact on listed share performance. He also recommended that further research be conducted since liquidity influenced only $4.6 \%$ of total variations in equities performance hence the need to undertake for further studies to analyze other variables that influence the share performance. The inventory control models of Brunner Meier and Pedersen (2006) imply a negative relationship between liquidity and idiosyncratic volatility. Chessar (2015) confirmed that the most significant factor that 
affected the stock market volatility of the listed firms was market capitalization, followed by liquidity respectively

In his study, Kihara (2011) noted a positive correlation between cash flows and the earnings. According to Spiegel and Wang (2005) nited that there was an inverse relationship between IV and liquidity, he further concluded that relationship between IV and returns could be explained by both liquidity and returns and between company size and return.Odongo (2008) investigated the effects of liquidity level on stock returns at the NSE found no evidence to link share prices to liquidity of the firms listed. The inventory control models of Brunner Meier and Pedersen (2006) imply a negative relationship between liquidity and idiosyncratic volatility.

Avanidhar, Sarkar, Chordia and Tarun, (2005) studied how large and small firms respond to crosssectional volatility, returns and liquidity in the United states. They concluded that large firms respond volatility and return and opposed to small capitalized firms, the study also found out that shocks persisted in volatile, high return and large capitalization spread, and response picked in few trading periods

\subsection{Methodology}

This study employs positivistic epistemology. A research philosophy is representing a belief about the process of data collection and analysis. (Levin, 1988. According to Bryman and Bell (2007), positivism is an epistemological position which studies social reality and beyond by employing natural sciences' methods. The positivistic philosophical strategy allows the researcher to set up hypotheses based on the existing theories that are relevant to the study. This study employed correlational and descriptive research design because it is based on the premise that if a statistically significant relationship exists between two variables, then it is possible to predict one variable using the information available on another variable.

Following the criterion employed by $\mathrm{Fu}$ (2009), the researcher targeted the stocks that were traded for a minimum of 15 days during each month of the sample period. For ease of analysis, the researcher considered only those shares that were present in all months from 1998 to 2017. Target and accessible population for this study comprised of the 39 listed companies that existed and their shares were actively traded at the NSE from 1998 to 2017. In this study, the researcher used census study, a census study is any inquiry of the entire population of a particular set of 'objects', it is a complete enumeration of all items in the population. The researcher collected annual published financial statements for all 39 sampled listed companies for the twentyyear period under study (1998 to 2017). The financial statements were obtained from specific listed company's websites and NSE handbook. An assistant was hired to extract the required data (Current asset and Current liabilities) for all sampled firms in all financial periods under review. The extracted data was keyed into a prestructured work sheet and then converted into STATA format.

The secondary data extracted from published financial statements was used to compute current ration which indicates the level of company's' liquidity position. The secondary data encompassed panel data which consists of time series and cross-sections. The panel data obtained was analyzed using descriptive statistics, correlation analysis, and panel regression analysis.

Autocorrelation, heteroscedasticity, and panel unit root tests were conducted to ensure proper specification. The panel methodology was supported by STATA software. Feasible Generalized Least Square estimation was performed after accounting for various violations of classical linear assumptions. The analysis of variance (ANOVA) was checked to reveal the overall model significance.

To estimate idiosyncratic volatility for sampled stocks at the NSE, the researcher employed the standard deviation of the regression residual $\left(\varepsilon_{i t}\right)$ from Single Index Model as outlined in Malkiel and Xu (2003).

$\mathrm{R}_{i, t}-\mathrm{R}_{\mathrm{f}, \mathrm{t}}=\alpha_{\mathrm{i}}+\beta_{\mathrm{i}}\left(\mathrm{R}_{m, t}-\mathrm{R}_{f, t}\right)+\varepsilon_{i, t}$

Where: $i=$ Specific stock,

$\mathrm{R}_{\mathrm{m}}=$ Return on the all ordinaries index

$\mathrm{t}=$ Time interval

$\mathrm{R}_{i, t}-\mathrm{R}_{\mathrm{f}, \mathrm{t}}=$ Excess return of firm $i$ in month $\mathrm{t}$

$\mathrm{R}_{m, t}-\mathrm{R}_{f, t}=$ Excess market return in month $\mathrm{t}$

$\varepsilon_{\text {it }}=$ regression residual.

The specific empirical model used in the study is defined as follows:

Yit $=\beta_{0}+\beta$ Xit $+\varepsilon i t$

Where;

$\mathrm{Y}$ it $=$ Idiosyncratic volatility of firm $i$ at time $t$;

$\mathrm{Xit}=$ Liquidity of firm $\mathrm{i}$ at time $t$;

$\beta_{0}=$ the constant term

$\beta_{\mathrm{s}}=$ The coefficients for the independent variable

Subscript $i=$ Firms (cross-section dimensions) ranging from 1 to 39 ;

Subscript $t=$ Years (time-series dimensions) ranging from 1998 to 2017; cit $=$ error term of the model. 


\subsection{Results and Findings}

Table 1 shows the mean, minimum, and maximum values with standard deviation of various variables used in the model for period 1998-2017.

Table 1: Descriptive Statistics

\begin{tabular}{lccccc}
\hline Variables & Obs & Minimum & Mean & Maximum & Std. Deviation \\
\hline Liquidity & 780 & 0.072 & 2.418 & 21.259 & 2.314 \\
Idiosyncratic Volatility & 780 & 2.044 & 26.000 & 28.890 & 4.251 \\
\hline
\end{tabular}

Table 1 shows all the variables share the same sample size of 780 observations. The mean value of liquidity was 2.418 with a minimum of 0.072 and maximum of 21.259 . The standard deviation for liquidity was 2.314 .

\subsection{Correlation Analysis}

The study conducted correlation analysis for liquidity on Idiosyncratic Volatility in order to examine the nature of the statistical relationships between the variables. Table 2 shows the correlation matrix of the variables included in the study.

Table 2: Correlation Matrix Results

\begin{tabular}{lcc}
\hline Variables & Idiosyncratic Volatility & Dividends Per share \\
\hline Idiosyncratic Volatility & 1.000 & 1.000 \\
Liquidity & $-0.4691^{* *}$ & \\
& 0.000 & \\
\hline
\end{tabular}

The results showed that liquidity $(-0.4691,0.000)$ had a negative and significance relationship with Idiosyncratic Volatility of stock returns among listed firms in Kenya.

\subsection{Diagnostics Test}

\subsubsection{Panel Unit Root Tests}

Unit root tests was conducted using the LLC test to establish whether the variables were stationary or nonstationary. The purpose of this is to avoid spurious regression results being obtained by using non-stationary series. Results in Table 3 indicated that the variables are stationary (i.e. absence of unit roots) at 5\% level of significance.

Table 3: Unit root

\begin{tabular}{lccc}
\hline Variable name & Statistic(adjusted) & P-value & Comment \\
\hline Idiosyncratic Volatility & 6.0376 & 0.010 & Stationary \\
Liquidity & 3.9380 & 0.003 & Stationary \\
\hline
\end{tabular}

The study therefore concludes that the two variables under consideration do not have unit root and are therefore used in levels. This means that the results obtained are not spurious (Gujarati, 2003).

\subsubsection{Heteroskedasticity Test}

Heteroscedasticity test was performed so as to determine if the error term is correlated across observation in the time series data. The error terms from a regression model must have a constant variance called Homoscedastic and to ensure whether the residuals meet this criterion of the study used the Breusch-Pagan test for Heteroscedasticity where the null hypothesis under this test is that residuals are Homoscedastic. If the p-value is $>0.05$, there is constant variance. The null hypothesis was therefore not rejected at a critical $p$ value of 0.05 since the reported value was 0.889 . Thus, the data did not suffer from statistically significant heteroscedasticity as shown in Table 4

Table 4: Heteroskedasticity Test Results

\section{Breusch-Pagan / Cook-Weisberg test for heteroscedasticity}

Ho: Constant variance

Variable: fitted values

Idiosyncratic Volatility

chi2(39) $\quad=\quad 59528.65$

Prob $>$ chi $2 \quad=\quad 0.889$

\subsubsection{Test for autocorrelation}

The study used Wooldridge test in order to detect the existence of autocorrelation in the data, the test assisted the researcher to know whether or not the residual is serially correlated over time and the results are shown in Table 5. The null hypothesis of this test was that there is no first order serial/autocorrelation existed in the data. The test statistic reported is F-test with one and 38 degrees of freedom and a value of 434.92. The P-value of the Ftest is 0.270 indicating that the F-test is not statistically significant at $5 \%$ level. Hence, the null hypothesis of no autocorrelation is supported and the study concludes that residuals are not auto correlated. 
Table 5: Serial Correlation Tests

Wooldridge test for autocorrelation in panel data

H0: no first-order autocorrelation

$\mathrm{F}(1,38)=434.92$

Prob $>\mathrm{F}=0.270$

\subsubsection{Hausman Test}

When performing data analysis, it is critical to ascertain whether to perform a random effects model or a fixed effects model (Baltagi, 2005). This will assist in making decision on the most suitable model to use, both random and fixed effects estimate coefficients. The researcher used Hausman's specification test (1978) to select between fixed and random effect models. Table 6 shows the results of Hausman test.

Table 6: Hausman Test for Idiosyncratic Volatility

\begin{tabular}{lcccc}
\hline & $\mathbf{( b )}$ & $\mathbf{( B )}$ & $\begin{array}{c}(\mathbf{b}-\mathbf{B}) \\
\text { Fifference }\end{array}$ & Sqrt (diag(V_b-V_B)) \\
& Fixed & random & D.E. \\
\hline Liquidity & 0.00235 & 0.00248 & -0.00014 & 0.00062 \\
chi2(4) & 0.76 & & & \\
Prob>chi2 & 0.944 & & & \\
\hline
\end{tabular}

The null hypothesis of the Hausman test is that the random effects model is preferred to the fixed effects model. Hausman test reveals a chi-square of 0.76 with a p-value of 0.944 indicating that at 5 percent level, the chi-square value obtained is statistically insignificant. Therefore, the researcher did not reject the null hypothesis that random effects model is preferred to fixed effect model for Idiosyncratic Volatility. Therefore, random effects model for Idiosyncratic Volatility was therefore adopted.

\subsection{Regression Analysis}

\subsubsection{Effect of liquidity on Idiosyncratic Volatility}

Regression analysis was conducted to determine whether there was a significant relationship between Liquidity and Idiosyncratic Volatility of stock returns among listed firms in Kenya. As presented in the Table 7, the coefficient of determination R Square is 0.3418 . The model indicates that Liquidity explains $34.18 \%$ of the variation in Idiosyncratic Volatility. This means $34.18 \%$ of the Idiosyncratic Volatility is influenced by Liquidity.

Table 7: Liquidity on Idiosyncratic Volatility

\begin{tabular}{lcccccc}
\hline Idiosyncratic Volatility & Coef. & Std. Err. & T & P $>|\mathbf{t}|$ & {$[\mathbf{9 5 \%}$ Conf. } & Interval] \\
\hline Liquidity & -0.022 & 0.004 & -5.440 & 0.000 & -0.031 & -0.014 \\
Cons & 26.100 & 0.023 & 1147.810 & 0.000 & 26.055 & 26.144 \\
R-sq: & 0.3418 & & & & & \\
F(1,779) & 28.59 & & & & & \\
Prob & 0.000 & & & & & \\
\hline
\end{tabular}

$\mathrm{Y}=26.1-0.022 \mathrm{X}$

Where: $\mathrm{Y}=$ Idiosyncratic Volatility

$$
\mathrm{X}=\text { Liquidity }
$$

The findings further confirm that the regression model of Idiosyncratic Volatility on Liquidity is negatively and significant with a coefficient of $(r=-0.022, p=0.000)$ supported by $F=28.59$. This is also confirmed by the $t-$ statistic value of 5.440 which was greater than the t-critical of 1.96. This implies that there exist a negative and significant relationship between Liquidity and Idiosyncratic Volatility since the coefficient value was negative and the p-values was 0.000 that is less than 0.05 . This means that a unitary increase in liquidity leads to a decrease in Idiosyncratic Volatility by 0.022 units holding other factors constant.

The results are consistent with Spiegel and Wang (2005) who found that idiosyncratic volatility and liquidity are inversely related and conclude that the relationship between idiosyncratic volatility and returns could be capturing both the relationship between liquidity and returns and the relationship between size and returns. Using the inventory control models Brunnermeier and Pedersen (2006) also found a negative relationship between liquidity and idiosyncratic volatility. The results contradicts Nyamai (2012) who studied the effects of cash management and firm's liquidity on share prices of companies listed at the NSE concluded that liquidity has a positive influence on Idiosyncratic Volatility and stock performance and Odongo (2008) who investigated the effects of liquidity level on stock returns at the NSE found no evidence to link share prices to liquidity of the listed firms.

\subsection{Hypotheses Testing}

The hypothesis to be tested was:

$\mathrm{H}_{0}$ : Liquidity has no significant effect on idiosyncratic volatility of stock returns among listed firms in Kenya.

The hypothesis was tested by using multiple linear regression and determined using p-value. The 
acceptance/rejection criteria was that, if the $\mathrm{p}$ value is less than 0.05 , we reject the $\mathrm{H}_{05}$ but if it is more than 0.05 , the $\mathrm{H}_{05}$ is not rejected. Regression results revealed that there was a negative and significant relationship between liquidity and Idiosyncratic Volatility of stock returns among listed firms in Kenya $(r=-0.020, p=0.000)$. This was supported by a calculated t-statistic of 3.777 that is larger than the critical t-statistic of 1.96 . The study therefore adopted the alternative hypothesis that liquidity has a significant effect on Idiosyncratic Volatility of stock returns among listed firms in Kenya.

\subsection{Conclusions}

Based on the findings, the study concluded that liquidity has a negative and significant effect on Idiosyncratic Volatility of listed firms in the Nairobi securities exchange. Liquidity plays a crucial role in the successful functioning of a business firm. Liquidity not only helps to ensure that a business always has a reliable supply of cash close at hand, but it is a powerful tool when it comes to determining the financial health of future investments as well. It principally has an effect on financial costs reduction or growth, changes in the sales dynamic, as well as it influences on company risk level. The decisive significance of liquidity means that it is important for company development and at the same is one of the fundamental endogenous factors that are responsible for company market position.

The significance of liquidity to company performance might lead to the conclusion that it determines the profitability level of company. The current ratio is used to test a firm's liquidity, that is, its current or working capital position by deriving the proportion of the firm's current assets available to cover its current liability. A higher current ratio indicates a larger investment in current assets which means, a low rate of return on investment for the firm, as excess investment in current assets will not yield enough returns. A low current ratio means smaller investment in current assets which means a high rate of return on investment for the firm, as no unused investment is tied up in current assets. The study therefore concludes that in order to minimise Idiosyncratic risk, a firm need to balance its liquidity position so as to avoid holding too much liquid asset at the expense of investment that yields returns or having a low Liquidity position and risk defaulting on its short-term obligations.

\subsection{Recommendations}

The study recommends that investors should consider liquidity in pricing firm specific risk. The study further recommends management to focus on developing financial accounting systems and processes that will result in realization of financial statements that reflect true and fair representation of the listed companies' financial position, they should also disclose all material information that is relevant for stakeholder's decision making. The study also recommends that the management should regularly monitor the company's liquidity ratio as this ensures sound and informed decisions that will increase the company's profits, drive growth and reduce Idiosyncratic risk. The the policy makers should embrace financial accounting indicators on their strategic decision-making, these indicators guide them in expanding the interpretation of the financial and other dynamics in the listed companies at the Nairobi securities market and other related firms.

\subsection{References}

Abken, A. and Nandi, (1996) Options and Volatility, Economic Review- Federal Reserve Bank of Atlanta Al-Farah, Almeri and Shanikat (2014).The Accounting Variables' Ability in Explaining the Volatility of Stock's Price: The Case of Amman Stock Exchange, European Journal of Management.

Amadi, S. N. and Odubo T. D. (2005): Macroeconomic variables and stock prices, casuality analysis, the Nigerian journal of economic and management studies.

Andabai, P. W. (2010). Dynamics of interest rate management and its impact on money supply in Africa: A theoretical approach. The University Advanced Research Journal, Issue 3, Jan-March, PP. 1-7

Akpan, I. (2004). Fundamentals of finance. Uyo: KIV Publishers.

Bergh, D. and Ketchen,D ( 2014) Signaling Theory and Equilibrium in Strategic Management Research: An Assessment and a Research Agenda. Journal of Management Studies 51:8.

Boloorforoosh, A. (2014). Is Idiosyncratic Volatility Risk Priced? Evidence from the Physical and Risk-Neutral Distributions. John Molson School of Business, Concordia University, 1455 de Maisonnuve Blvd. W, Montrea.

Bushee, B. and Noe F. (2000): Corporate disclosure practices, institutional investors and

Creswell, W. (1994), Research Design: Qualitative and Quantitative Approaches, Sage: Thousand Oaks.

De Medeiros and Lago (2014). Disclosure of Accounting Information and Stock Return Volatility in Brazil. Research Gate. Sao Paulo. Brazil

Deloite Plus (2015). IFRS in your pocket 2015, Deloitte IFRS Publications

Drew, M. Naughton, T. (2004). Is idiosyncratic volatility priced? Evidence from the Shanghai Stock Exchange. International Review of Financial Analysis. 
Easterbrook, F.H. (1994). Two Agency-cost Explanations on Dividends. American Economic Review, 74.

Fazil (2013). Does Idiosyncratic Volatility Matter in The Emerging Markets? Istanbul Stock Exchange Evidence. Ankara University, Faculty of Political Sciences. Turkey

Fernanda, M. and Pinto (2012). The Relationship between Idiosyncratic Risk and Returns in the Brazilian Stock Market, Pontifical Catholic University of Rio de Janeiro. Brazil.

Francis J. and K. Schipper (1999): Have financial statements lost their relevance? Journal of Accounting Research.

Frees,E ( 2004). Longitudinal and panel data analysis and application in the social science, Cambridge University press.

Fu, F. (2009), "Idiosyncratic risk and the cross-section of expected stock returns. " Journal of Financial Economics, Vol.91, Issue1.

Gachucha K. (2014) An examination of the relationship between financial management Practices and stock returns of listed companies in the Nairobi securities exchange. University of Nairobi. chss.uonbi.ac.ke/sites

Gleason, C. and Lee, C. (2003). Analyst forecast revisions and market price discovery. The Accounting Review.

Gujarati N. (2003) Basic econometrics, McGraw-Hill international editions: Economic series $4^{\text {th }}$ edition McGraw Hill.

Hashemijoo, M. and Ardekani, M. (2012). The Impact of Dividend Policy on Share Price Volatility in the Malaysian Stock Market, Journal of Business Studies Quarterly.

Halonen, E., Pavlovic, J. and Persson, R. (2013). Value relevance of accounting information and its impact on stock prices: Evidence from Sweden. Stockholm University, Department of Economics. Econometrics.

Hodrick, R. J., Xing, Y., and Zhang, X. (2009). High idiosyncratic volatility and low returns: international and further U.S. evidence. Journal of Financial Economics.

Huang,C (2014) Analysis on Financing Difficulties for SMEs due to Asymmetric Information School of Management, Guangdong University of Technology, Guangzhou, China. Global Disclosure of Economics and Business, Volume 3, No 2.

Hussainey, K. and Mgbame, C. (2011). Dividend policy and share price volatility: UK evidence. Journal of Risk Finance.

Kihara D.G (2011).The relationship between dividends announcements and return on investments: case study of companies quoted at NSE. University of Nairobi.

Keynes, J. M. (1936). The general theory of employment. interest and money. New York: Harcourt Brace and World

Jhingan, M.L. (2004). Money banking international trade and public finance. India: Vrinda Publications [P] Ltd.

Macharia, (2013). Effect of financial performance indicators on shareholders' value among listed commercial banks in Kenya, IJMBS Vol.3. July 2013. JKUAT.

Maina J. (2009). An empirical investigation of stock returns reaction around earnings announcements for quoted companies at NSE. MBA project, University of Nairobi.

Malkiel, B. and Xu Y. (2003) Investigating the Behaviour of Idiosyncratic Volatility. Journal of Business.

Malkiel, B., Xu, Y. (2006), Idiosyncratic Risk and Security Returns, Working paper, Princeton University.

Malkiel, Burton G., and Xu, Y. (2006), idiosyncratic risk and security returns, working paper, University of Texas at Dallas.

Mandal, N. (2013) Sharpe's single index model and its application to construct optimal portfolio: an empirical study. Great Lakes Center for management research, Vol.7, No.1.

Miller, M. and F. Modigliani, (1961). Dividend policy, growth, and the valuation of shares. Journal of Business 34.

Milton, Queensland, OR CPA Australia (2016) Accounting Handbook 2016, Pearson Education Australia.

Naceur, B. andNachi, W. (2007). Does the Tunisian accounting reform improve the value relevance of financial information? Afro-Asian Journal of Accounting and Finance.

Nikkinen, J., Omran, M. M., Sahlström, P., \& Äijö, J. (2008). Stock Returns and Volatility Following the September 11 Attacks: Evidence from 53 Equity Markets. International Review of Financial Analysis, 17, 27-46.

Nyamai, C. N. (2012). The effects of cash management and firm's liquidity on share prices of companies listed at the Nairobi Securities Exchange. MBA project, University of Nairobi

Odongo, P.W. (2008). The effects of liquidity level on stock returns: The Nairobi Securities Exchange evidence. University of Nairobi

Okpara, G. (2010). The cost of capital corporation and the theory of investment. American Economic Review, 32 (14)

Pastor, L. and P. Veronesi. (2003). Stock Valuation and Learning about Profitability. Journal of Finance.

Poitevin, M. (1989) "Financial Signaling and the "Deep-Pocket" Argument" The RAND Journal of Economics 20(1) 
Riscura (2013). RisCura SAVCA Private Equity Performance Report Q3 2013Ross. A (1977). "The Determination of Financial Structure: the Incentive-Signaling Approach.” the Bell .Journal of Economics

Sharpe F. (1964). Capital Asset Prices, Journal of Finance, September 1964, pages 42- 442.

Sharma, S. (2011).Determinants of Equity Share Prices in India. Journal of Arts Science and Commerce.

Spiegel, M., Wang, X. (2005), Cross-sectional variation in stock returns: liquidity and idiosyncratic risk, working paper, Yale University.

Stock return volatility, journal of accounting research (studies on accounting information and the economics of the firm).

Uchendu, O. A. (2010, March). Interest Rate Policy, Savings and Investment in Nigeria. Economic and Financial Review, 31(1).

Tran, N. and Nguyen, T. (2015) Market Efficiency and Idiosyncratic Volatility in Vietnam. School of Finance, University of Economics Ho Chi Minh City, Vietnam. International Journal of Business and Management; Vol. 10, No. 6;

Tuli, Nishi and Mittal, R.K. (2001). Determinants of Price-Earnings Ratios. Finance India.

Waithaka, A. (2012) The relationship between working capital management practices and financial performance of agricultural companies listed at the NSE. University of Nairobi.

Wang and Chang (2008) The Association Between Accounting Information Disclosure and Stock Price, National Taipei University. Taiwan

Wang, J., Fu, G. and Luo, C. (2013). Accounting Information and Stock Price Reaction of Listed Companies; Empirical Evidence from 60 Listed Companies in Shanghai Stock Exchange, Journal of Business \& Management.

Williams, N. Grajales, C. and Kurkiewicz, D. (2013) Practical assessment, Research and evaluation. Assumptions of Multiple Regression: Correcting Two Misconceptions. A peer-reviewed electronic journal. Volume 18, Number 11.

Wilson (2010) Structured research approach with a sample of the population. Boston: Irwin McGraw-Hill

Woo C. (1981). Market share leadership -Does it always pay off? Proceedings of the Academy of Management.

Wood F, and Sangster (2012) Frank Woods's business accounting 1, 12 ${ }^{\text {th }}$ edition, Pearson Education Limited.

Wood, F. and Alan S. (2005). Business Accounting 1 (10th ed.).London: Prentice Hall.

Wooldridge, J.M., (2007), Econometric Analysis of Cross Section and Panel Data (second ed.) MIT Press.

Xing, Y. and Zhang, X. (2008). The cross-section of volatility and expected returns. Journal of Finance, 61 (1), 259-299.

Yang, L. (2008). Making Strategy Work: A Literature Review on the Factors Influencing Strategy Implementation. ICA Working Paper 2/2008. Lugano Switzerland Institute of Corporate Communication.

Yu, H., and Huang, Y. (2005). A Positive Analysis on the Relationship between Stock Prices of Shanghai Market and Company Financial Report. Commercial Research.

Zhou, J. (2004). Analyzing the Dynamic Relationship between Stock Price and the Earnings by Using the Time Series. Modern Finance and Economics. 